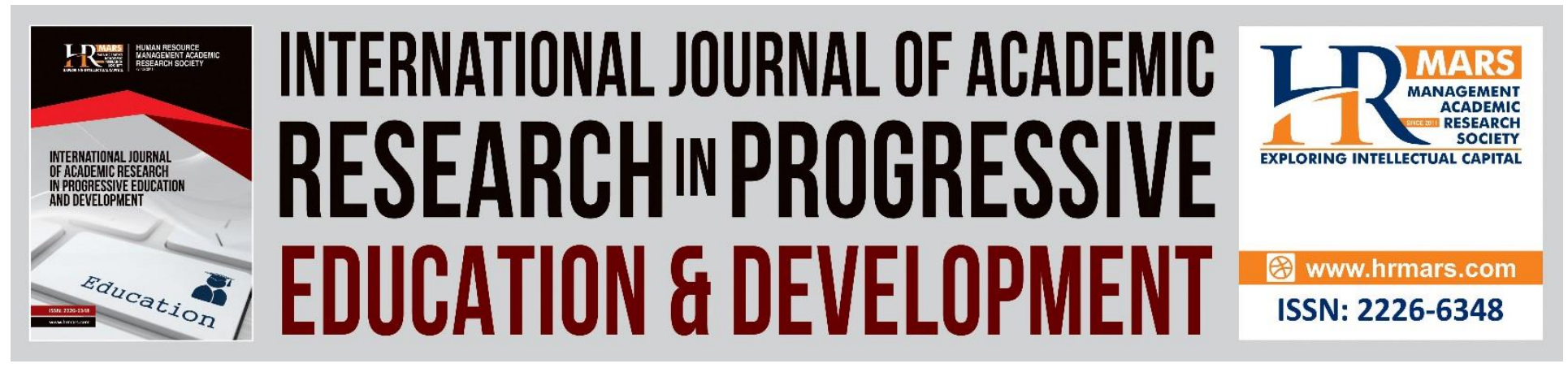

\title{
Adequate Fire Safety Training for the Occupants Knowledge and Awareness of Fire Safety
}

\author{
Alao, Mohammed Kaseem, Yahya Mohamad Yatim and Wan yusoff wan \\ Mahmood
}

To Link this Article: http://dx.doi.org/10.6007/JJARPED/v10-i1/8580

DOI:10.6007/IJARPED/v10-i1/8580

Received: 23 December 2020, Revised: 20 January 2021, Accepted: 31 January 2021

Published Online: 15 February 2021

In-Text Citation: (Alao et al., 2021)

To Cite this Article: Alao, M. K., Yatim, Y. M., and Mahmood, W. Y. W. (2021). Adequate Fire Safety Training for the Occupants Knowledge and Awareness of Fire Safety. International Journal of Academic Research in Progressive Education and Development, 10(1), 13-24.

Copyright: (C) 2021 The Author(s)

Published by Human Resource Management Academic Research Society (www.hrmars.com)

This article is published under the Creative Commons Attribution (CC BY 4.0) license. Anyone may reproduce, distribute, translate and create derivative works of this article (for both commercial and non-commercial purposes), subject to full attribution to the original publication and authors. The full terms of this license may be seen at: http://creativecommons.org/licences/by/4.0/legalcode

Vol. 10(1) 2021, Pg. 13 - 24

http://hrmars.com/index.php/pages/detail/IJARPED

JOURNAL HOMEPAGE

Full Terms \& Conditions of access and use can be found at

http://hrmars.com/index.php/pages/detail/publication-ethics 


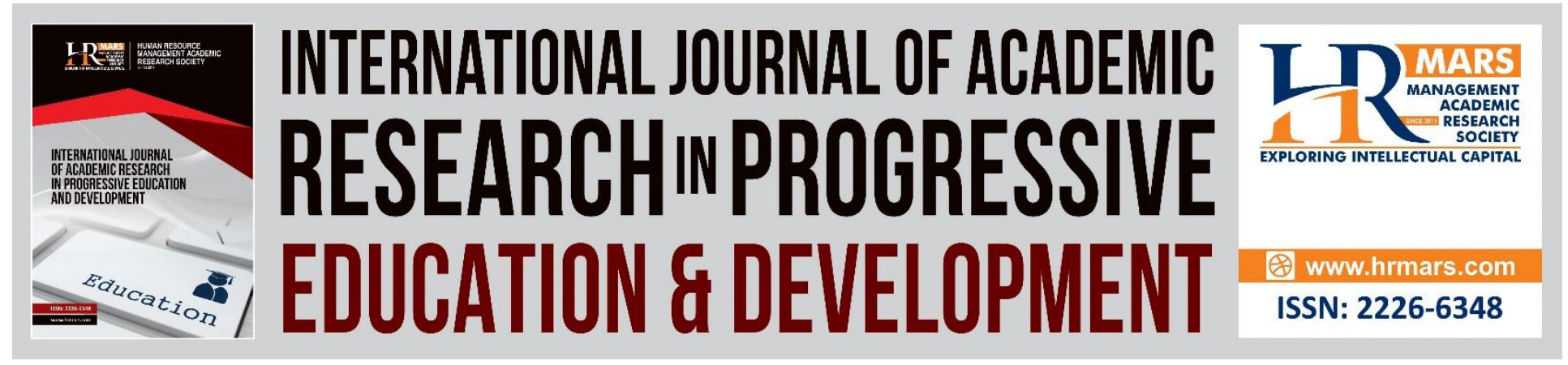

\title{
Adequate Fire Safety Training for the Occupants Knowledge and Awareness of Fire Safety
}

\section{Alao, Mohammed Kaseem, Yahya Mohamad Yatim and Wan Yusoff Wan Mahmood}

Department of Quantity Surveying, Faculty of Built Environment and Surveying

Universiti Technologic Malaysia

Email: kaseem@graduate.utm.my,b-yahya@utm.my,b-wyusof@utm.my

\begin{abstract}
Achievement of fire safety objectives in buildings for the safety of lives, property conservation and business continuity is a collective responsibility of all the stakeholder, and its depends on the level of fire safety knowledge and awareness of the concern stakeholders. Therefore, this research was conducted to determine the fire safety training needs of fire safety practitioners and building managers for adequate fire safety knowledge and awareness of the building occupants in Nigeria. The research adopted questionnaires survey research design. The research population for the study comprises of 349 building manager and fire safety practitioners from six (6) north-central states of Nigeria. A research questionnaires was design for the study, the questionnaires was distributed to collect the data from the participants and was validated by experience fire safety experts; the Cronbach alpha reliability approach was used to identified the internal consistency of the questionnaires items at 0.933. the collected data were analyzed through CFA using SPSS and AMOS software, after the analysis, the data from the participants were adjudge appropriate for inclusion into the confirmatory factor analysis. The CFA was carried out and finding from the analysis is in agreement with one-factor model of fire safety training program for the enhancement of the occupant's fire safety knowledge and awareness. The research found that fire safety practitioners and building manager requires the components for effective fire safety training. Therefore, it was suggested that the stakeholders should prioritize adequate fire safety training of the occupants and public in the fire safety for boosting their knowledge and awareness of fire safety

Keyword: Fire Safety, Awareness, Components, Confirmatory Factor Analysis, Fire Training, Buildings.
\end{abstract}

\section{Introduction}

The level of fire safety awareness and knowledge among the building occupants, owners, and manager, can help in enhances the safety of the building and its environment (Agyekum, Ayarkwu, \& Ayarkwa, 2016). Fire safety is the complement of the risk, and whenever there is an 
increase in the level of fire safety, and then there would be a decrease in the level of fire risk. Fire is one of the utmost threat to human existences and also to the occupants, contents, and its environment. The fire outbreak does not respect the economic values of the building; neither does it exempt the occupants and the contents. Therefore, until now, the fire has damage, killed, injured, and destroyed many outstanding properties across the world. Fire disasters cause injured killed, and destruction to the building occupants and direct property damage to the building owners or developers (A, 1990). The possibility of fire safety in the building and the level of damages fire can cause is mostly dependent on the level of the occupant's knowledge, and awareness of fire safety measure and as well as the level of useful fire safety management (FPA, 2009) The level of modern building and the method of construction with the recent technology and facilities lead to concerned about getting everybody involved in the safety of building, contents, and occupants in terms of fire (Ferrontato \& Torretta, 2019). Adequate fire safety training equip the building occupants and general public on how to prevent fire disasters by equipping the occupants with the relevant knowledge and awareness of fire safety measures, the skill of using fire safety equipment, and knowledge of existing combustible materials in the building. Therefore, modern building has become more complicated; however, a more holistic approach to building management is required in order to tackle the complexities and innovation that exist in modern building facilities (Howarth, 1999)

According to Santin (2016), revealed that buildings fire has the highest yearly rate of the likelihood of fire disaster than any other environment. Furthermore, fire statistics from across the world highlighted that fire disasters in buildings are higher than any other place, such as forest fire. Hence, this study focused on determining the effect of fire safety training needs of building managers for safety and adequate knowledge and awareness of buildings occupants, building owners and the public for the achievement of fire safety objectives in the north-central states of Nigeria

\section{Statement of the Problem}

Management of fire in a building is a collective responsibility of all the occupants, building owners, the public, and the government (Ho, 2009). Thus, fire is an excellent servant to mankind, become an enemy when it is not needed, therefore, when fire outbreak occurred in the building, every stakeholder mentioned above, are usually the potential looser, therefore, to ensure that fire disaster is prevented from the occurrence, adequate fire safety training of the stakeholders is required in order to enhance the knowledge of all the stakeholders become paramount. (Kodure, 2019)

Therefore, to achieve practical training of the stakeholder's considerable guidelines is required from the building management to carry out fire safety training adequately. In addition, inadequate fire safety guidelines for the building managers and fire safety manager has been identified as the causes of poor fire safety knowledge and awareness amongst the stakeholders in fire safety. All the stakeholders include the occupants required the skills of fire safety knowledge and awareness. Besides, building occupants cannot attempt to quench the fire at ignition point before its spread and also, due to inadequate knowledge of fire safety system, they may not be able to use available fire safety equipment, neither will the occupants know the direction of escape route for quick and safe evacuation. Hence, these challenges mentioned 
Vol. 10, No. 1, 2021, E-ISSN: 2226-6348 @ 2021 HRMARS

above usually lead to fire destruction of buildings, closures of business activities, death, and injured to the building occupants. Therefore, this informed the study to determine the components needs of building managers, for safety managers for practical fire safety training among the stakeholders in the fire safety in the northern-central states of Nigeria (Debora, 2019)

\section{Purpose of the Study}

The aim of this study is to determine the fire safety training needs of fire safety managers for effective fire safety awareness and determine the construct validity of the model based on confirmatory factor analysis.

\section{Research Questions}

A. what are the fire safety training improvement needs of fire safety management for achievement of fire safety objectives?

B. How valid are the fire safety training in achieving fire safety objectives base on the Confirmatory Factor Analysis Model?

\section{Literature Review}

Fire safety in building refers to fire prevention, protection, minimizing the fire/smoke spread, and encouraging fast/ safe evacuation of the occupants during fire events (Groner, 2016). According to Ranchi (2013), fire safety in the building is an act of minimization of the potential for harm to life due to fire disasters in buildings (Shokouhi et al., 2019). Therefore, fire risks with several casualties usually lead to questions on fire safety needs in buildings concerning the level of occupants that were in the buildings where the fire events took place (Qureshi, 2018). Moreover, Chow (2001) suggested that in order to achieve simple fire safety objectives in buildings. It is pertinent to adequately train the building occupants on fire safety measure for practical knowledge and awareness of fire safety measures in buildings

The results of poor fire safety knowledge and awareness are particularly severe in the building where there are high combustible materials that can easily ignite fire (Campbell, 2020). Georgia (2018), Suggested that fire safety objectives, which include life safety, property conservative, and business continuity and minimizing the fire threat to the environment and social-economic development. All these objectives above are essential for the safety of the social-economic, political development of a country.

Therefore, a study was carried out in Nigeria to determine the level of relationship between fire safety knowledge and awareness among the building occupants and the rate of fire disaster casualties and damages, the results, however, revealed that occupants knowledge of fire and awareness of fire safety measures have a significant effect on the level of fire disaster casualties and damages, and also the rate at which fire can compete effectively with manage, as the occupants with adequate fire safety measure can effectively quench fire at ignition stage before it spread (Nimlyat, Audu, \& Gwatau, 2017). According to, incidents of fire disaster in Nigeria will not reduce until the public, and the building occupants are adequately equipped with the fire safety knowledge and awareness and adequately train, educated on their responsibility in fire prevention and management. Also revealed that majorities of Nigeria are not aware of their 
responsibility in fire safety; neither will they believe that the safety of life and property is the collective responsibility of everybody.

The success of any building management program irrespective of how it has appropriately mainly planned depends on the quality of fire safety manager and building manager, respectively. Therefore, the main obstacle that usually confronts the achievement of a valid fire safety management in Nigeria buildings is primarily the uses of inexperience and incompetent building manager, some managers of building in Nigeria lack knowledge of fire safety system in buildings which make them incompetent to accomplish their purpose of training the occupants and the general public the required fire safety knowledge and awareness effectively. According to Yayun (2016), equipping the building occupants and the general public with adequate fire safety knowledge and achieving fire safety objective is based on several factors which are fire warden, firefighting policy, fire safety evacuation route, fire safety arrangement, location of combustible materials, the duties of all the stakeholders, fire safety emergency training, firefighting equipment handling and fire warning devices.

The report from the federal fire services department in Nigeria indicated that occupants of the building and general public are not awareness of fire safety measures, because of inadequate knowledge and lack of fire training. However, the fire authority and practitioners have to provide the general public and building occupants with adequate knowledge and skill on fire safety in so doing, enhancing their knowledge and awareness on how to tackle fire effectively before its spread. It means that building managers or fire safety managers who execute the fire safety management program need to be well prepared, especially educating the public, which is currently lacking in Nigeria.

It has become pertinent for the managers of building to effectively educate, create awareness among the occupants and general public to understand exactly what to do and how to act before, during, and after fire events in order to prevent fire incidents. According to $M$ (2009) educating the public, creating awareness on how to prevent fire disaster and fire safety measures has a significant effect on the achievement of fire safety training objectives. Fire safety training has the potential to reduce fire risk in buildings.

\section{Fire Safety Training}

The fire safety training is an act of equipping the public, and occupants the fire safety knowledge and awareness in order to recognize the danger of fire; the ability to know what to do in order to prevent fire as well as action to take whenever there is fire. The primary focus of fire training is based on the knowledge about fire risks, the likelihood of several causes of fire disasters, and the likely effect on the built and natural environment (Kuru, Omuteremu, \& Nyandiko, 2017).

Furthermore, it revealed that fire safety training has three objectives, which are life safety, property conservative, and business continuity. Thereby, proper fire safety training is required to be developed in order to achieve these objectives (Martin, 2013). Suggested that fire safety training must do with equipping occupants with fire safety training should involve the equipping occupants with the relevant knowledge and skills about fire safety measures in order to achieve fire safety objectives. Moreover, fire safety training should be updated with required to achieve an acceptable level of fire safety. However, Chow (2001), asserted that fire safety training should 
Vol. 10, No. 1, 2021, E-ISSN: 2226-6348 @ 2021 HRMARS

be carried out on the general public, and all the building owners should be made to take fire safety very seriously. Adequate fire safety training, particularly for the building owners, occupants and general public, is very critical in buildings such as residential, commercial, institution, industrial building have a higher possibility for unforeseen fire outbreak

\section{Methodology}

This paper made use of a survey research design. According to Ali (2006), stated that a survey research design is a descriptive study that uses the samples of an investigation to the document; it explains and describes what is inexistent on the actual position of the phenomena under investigation. The study adopted 349 fire safety managers, building managers, facility managers and other relevant stakeholders in the field of fire safety across the North-central states of Nigeria. Two types of research questions were considered to guide the study. A questionnaire survey was used to collect the information from the participant, which was validated by fire safety experts from the study area. Cronbach alpha reliability was adopted to define the internal consistency of the questionnaires items at 0.933 . The collected data were analyzed using confirmatory factors analysis (CFA) using SPSS and AMOS software. The survey research design is appropriate for this research as data were gotten through the uses of questionnaires survey on the required components needs of building managers of fire safety objectives.

\section{Results Analysis}

In order to answers the questions from this study and attained the research purpose, the study made used of IBM-SPSS and AMOS software for the data analysis the table (1), illustrate the demographic information's of the participants and most of which are Building Managers and Fire Safety Practitioners selected from the study areas. There were Architect, Builders, Quantity Surveyors, Facility Managers, Engineers and Fire Safety Experts, and many of the participants have spent many years in the field of fire safety.

Table 1: showing the Demographic Information's of the Participants

\begin{tabular}{|l|l|l|l|}
\hline S/NO & Demographic Information & Frequency & Percentages\% \\
\hline A & Position of the Participant & & \\
\hline 1 & Building Manager & 102 & $29.2 \%$ \\
\hline 2 & Facility Manager & 50 & $14.3 \%$ \\
\hline 3 & Fire Safety Manager & 60 & $17.2 \%$ \\
\hline 4 & Building Maintenance Manager & 78 & $22.3 \%$ \\
\hline 5 & Fire Safety Director & 58 & $16.9 \%$ \\
\hline & & & \\
\hline
\end{tabular}


INTERNATIONAL JOURNAL OF ACADEMIC RESEARCH IN PROGRESSIVE EDUCATION AND DEVELOPMENT

Vol. 10, No. 1, 2021, E-ISSN: $2226-6348$ @ 2021 HRMARS

\begin{tabular}{|l|l|l|l|}
\hline S/NO & Demographic Information & Frequency & Percentage \% \\
\hline B & Professional Affiliation & & \\
\hline 1 & Architects & 97 & $28.8 \%$ \\
\hline 2 & Builders & 88 & $25.2 \%$ \\
\hline 3 & Quantity Surveyor & 78 & $22.3 \%$ \\
\hline 4 & Engineers & 47 & $13.4 \%$ \\
\hline 5 & Fire Safety Experts & 39 & $11.1 \%$ \\
\hline
\end{tabular}

\begin{tabular}{|l|l|l|l|}
\hline S/NO & Demographic Information & Frequency & Percentage\% \\
\hline C & Years of Working Experience & & \\
\hline 1 & $1-5$ years & 43 & $12.3 \%$ \\
\hline 2 & $6-9$ years & 38 & $10.8 \%$ \\
\hline 3 & $10-14$ years & 103 & $29.5 \%$ \\
\hline 4 & $15-19$ years & 101 & $28.9 \%$ \\
\hline 5 & $20-30$ years & 64 & $18.3 \%$ \\
\hline
\end{tabular}

\begin{tabular}{|l|l|l|l|}
\hline S/NO & Demographic Information & Frequency & Percentage\% \\
\hline D & Academic Qualification & & \\
\hline 1 & National Diploma & 84 & $24.0 \%$ \\
\hline 3 & Higher National Diploma & 72 & $20.6 \%$ \\
\hline 4 & Bachelor Degree & 103 & $29.5 \%$ \\
\hline 5 & Master Degree & 51 & $14.6 \%$ \\
\hline 5 & PhD Degree & 39 & $11.1 \%$ \\
\hline
\end{tabular}

From Table (2), the fire safety practitioners and building managers used for the pilot survey exercise were 21 in numbers. Therefore, the questionnaires for the pilot survey were distributed among the 20 participants and all were retrieved. $5 \%$ of the total 0 f 410 expected participants was used for the pilot survey. (Chandrashekara, 2012), suggested that, if there is an existing issues with respect to $5 \%$ likelihood of potential research participants, then the issues most likely be determine with $95 \%$ of confidence. In addition, Table (3), indicate that the reliability of the research instrument adopted for this study. According to Santos

(2009) Cronbach alpha usually measures for the scale reliability of 0.7 as the benchmarks. According to Santos (2009), revealed that a values that higher than 0.7 shows satisfactory reliability. From table (2), the Cronbach alpha coefficient for the instrument adopted for this study is highly satisfactory value at .933, which is higher than the satisfactory value and benchmarks of 0.7 . 
INTERNATIONAL JOURNAL OF ACADEMIC RESEARCH IN PROGRESSIVE EDUCATION AND DEVELOPMENT

Vol. 10, No. 1, 2021, E-ISSN: 2226-6348 @ 2021 HRMARS

Table 2: Case Processing Summary

\begin{tabular}{|c|c|c|c|c|}
\hline & & $\mathrm{N}$ & & $\%$ \\
\hline VCases & Valid & & 34 & 100.0 \\
\hline & Excluded $^{a}$ & & 0 & 0 \\
\hline & Total & & 34 & 100.0 \\
\hline
\end{tabular}

Table 3: Reliability Statistics

\begin{tabular}{|c|c|}
\hline $\begin{array}{l}\text { Cronbach's } \\
\text { Alpha }\end{array}$ & $\mathrm{N}$ of Items \\
\hline .933 & the \\
\hline
\end{tabular}

\section{Confirmatory Factor Analysis Model of Fire Safety Training needs}

This section presents the initials and final confirmatory factors analysis model, with the required model fitness as shown in Table (4)

Table 4: The three Categories of Model Fit and level of Acceptance

\begin{tabular}{|l|l|l|l|}
\hline & Name of Category & Name of Index & Level of Acceptance \\
\hline 1 & Absolute Fit & Chi-square & P-value $<0.05$ \\
\hline & & RMSEA & RMSEA $<0.08$ \\
\hline & & GFI & GFI $>0.090$ \\
\hline 2 & Incremental Fit & CFI & CFI $>0.90$ \\
\hline & & TLI & TLI $>0.90$ \\
\hline & & NFI & NFI $>0.90$ \\
\hline 3 & Parsimonious Fit & Chisq/df & Chisq $/$ df $<5.0$ \\
\hline
\end{tabular}

Sources: Olugbenga (2018), Awang (2015)

The initial confirmatory factor analysis of fire safety training (FAR), towards the achievement of fire safety objectives by the building managers, is showing in the figure (1), the confirmatory factor analysis of the participants at this level do not follow the required fitness model as shown in table (4), as a result of RMSEA which stood as follows: RMSEA =.196, Chi-square=287.843, $\mathrm{DF}=20$, Ratio=14.392, $\mathrm{P}=.000, \mathrm{CFI}=.885, \mathrm{IFI}=.885, \mathrm{TLI}=.839$, and $\mathrm{NFI}=.878$. Thus, the confirmatory Factor Analysis Model of Fire Safety Training consists of 8(eight) variables, as shown in the Figure (1) below. 
Vol. 10, No. 1, 2021, E-ISSN: 2226-6348 @ 2021 HRMARS

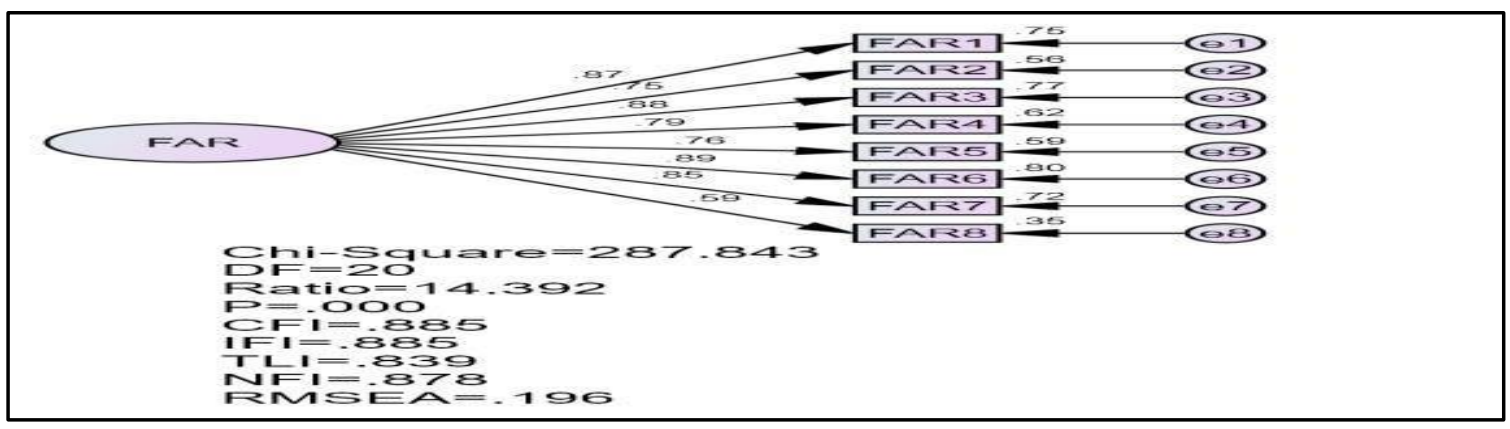

Figure 1: Initial CFA of Fire Safety Training Model

Finding from figure (2) validated the notable factors loading within the allowable brink after trimming was carried out to achieved the fitness of the model. However, the modification indices (MI) in table (5) indicated were all checked and the measurement error of 1 and 2, 2 and 8, as well as 5 and 6 , which were regarded to be higher than the allowable value of 15.00 . Subsequently, the items, which are redundancy, were modified using covariance, and the model fitness was attained.

Table 5: showing the modification indices for CAF of Fire Safety Training Needs.

\begin{tabular}{|ll|rl|}
\hline & & M.I. & Par Change \\
\hline e7 $<->>$ & e8 & 16.077 & -.058 \\
e6 $<->$ & e8 & 4.544 & -.027 \\
e6 $<->$ & e7 & 26.192 & -.038 \\
e5 $<->$ & e8 & 12.561 & .058 \\
e5 $<->>$ & e6 & 7.448 & -.024 \\
e4 $<-->$ & e7 & 29.320 & .058 \\
e3 $<->>$ & e7 & 48.134 & .056 \\
e3 $<->>$ & e4 & 7.981 & -.028 \\
e2 $<-->$ & e8 & 55.748 & .132 \\
e2 $<-->$ & e6 & 9.515 & .029 \\
e2 $<-->$ & e5 & 4.443 & .025 \\
e2 $<-->$ & e3 & 10.315 & -.032 \\
e1 $<-->$ & e7 & 7.215 & -.023 \\
e1 $<-->$ & e6 & 28.396 & .039 \\
e1 $<-->$ & e3 & 5.739 & -.019 \\
e1 $<->>$ & e2 & 6.212 & -.026 \\
\hline
\end{tabular}

The modified confirmatory factors analysis for Fire Safety Training towards achieving fire safety objectives in Nigeria is shown in Figure (2). The covariance of items FAR1, FAR2, FAR5, FAR6 and FAR8 improves the modification indices standards. However, the results attained are as follows: Chi-square= 35.217, DF=11, Ratio=3.202, $\mathrm{P}=.000, \mathrm{CFI}=.986, \mathrm{IFI}=.987, \mathrm{TLI}=.974, \mathrm{NFI}=.981$ and RMSEA $=.080$, subsequently, the model fitness was achieved 


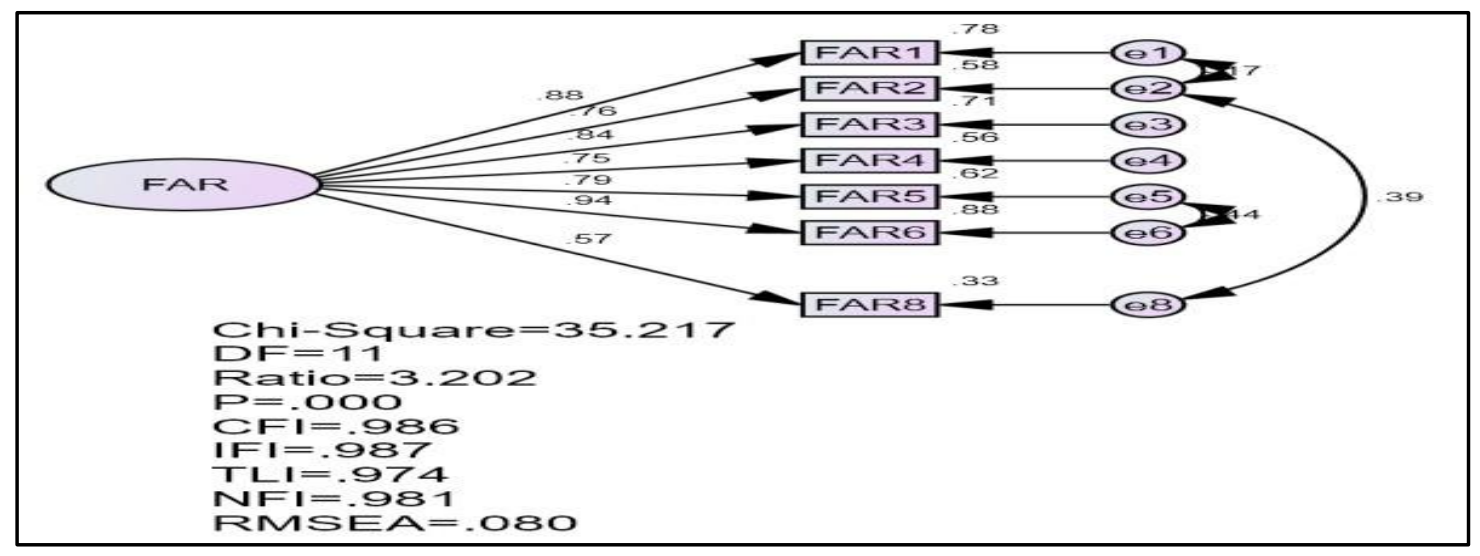

Figure 2: Final CFA of Fire Safety Training Model

\section{Discussion of Results}

The results of this study shows that effective fire safety-training program enhances the achievement of fire safety objectives in building. The finding from the demographic data revealed that building manager has the highest percentages of participants with $29.2 \%$, Architects are the highest numbers of participants in the survey among the participated professionals with the percentage of $28.8 \%$, the years of working experiences of the participated professional revealed that, the participated professional have acquired significant years of experiences which ranges from 10 to 14 years (29.5\%), and the result from the academic qualification of participated professionals signified that the participants possess the relevant qualification to partake in the survey. However, considering the findings from the demographic data, it implied that the data collected is highly significant.

The finding from this study are in agreement with the results of a study by Nachtigall (2017), who established that managers of building needed improvements in fire safety training program to enhances their competence for the achievement of fire safety objectives in building. This findings is also in covenant with the perception of Ayu (2018), who found that effective training on firefighting policy will enhances the fire safety knowledge and awareness of occupants, and improve the achievement of fire safety objectives. Confirmatory factor analysis (CAF), as applied in this paper is a statistics approach adopted to confirm the factor arrangement of a apparent variables, it permit the researcher in control the relationship that exist between observed and latent variables concepts. The research present the initial and final confirmatory factor model of individual components. In order to declares a model fitness and satisfactory, there are certain criteria that must be met which comprises of all the factor loading to be equal or lesser than 0.5.

In addition, the modification indices which includes CFI, IFI, TLI and NFI, should be above 0.90 , the ratio of the Chi-square and the degree of freedom suggested ranging from as high as 5.0 to as low as 2.0 (Todaro \& Fideli, 2007); (Wheaton, Muthen, \& Alwin, 1977), and RMSEA < 0.08. The CFA carryout in order to establish the findings indicate that items FAR1 (firefighting policy training), FAR2 (fire safety evacuation plan training), FAR3 (training on the location of combustible materials), FAR4 (training on the duties of stakeholders), FAR5( fire safety emergency training), FAR6 (training on fire safety risk), FAR7 (firefighting equipment training), 
Vol. 10, No. 1, 2021, E-ISSN: 2226-6348 @ 2021 HRMARS

FAR8 (training on fire warning device) were confirmed authoritative and effective for the achievement of fire safety training in Nigeria.

The revised model revealed confirmatory factor analysis of fire safety training program and individual items of the model indicated an acceptable factor loading of higher than 0.5 as needed and the model shows satisfactory model fitness, which indicated that the model developed adopted for fire safety training program for enhancing the fire safety awareness and knowledge of occupants in Nigeria.

This research finding is in the agreement with the suggestion of Yayun (2016), Evert (2018), Howarth (1999); Ebenechi (2017); Ogbonna (2015); Mufida (2018) and Berlet (2018). The results outcome of these aforementioned researchers are in agreement with the validating the finding of this study for the components required for effective fire safety training program for the purpose of improving the competence of fire safety manager, building manager, facility and fire safety practitioners in achieving fire safety objectives in Nigeria.

\section{Conclusion}

Fire safety is a global issue that required attention of all the stakeholders; this is due to the higher fire risk, which has negative effects on the life of occupants, property preservation, business continuity and social economic development. This research has recognized that building manager, fire safety manager and fire safety practitioners required adequate fire safety training program to improve their competency for effective fire safety knowledge and awareness of the occupants there is urgent needs for the building manager and fire safety practitioners to impart both the knowledge and awareness of fire safety measure, for prevention and control with the uses of effective components of fire safety training program to enhances the fire safety awareness and knowledge on the occupants. The study therefore, recommend that absolute implementation of fire safety training program as revealed in this research and also suggested that other states in Nigeria can domesticate the results of this study for the achievement of fire safety objectives in buildings

However, in order to achieve higher degree of safety of occupants, property conservation, business continuity and social-economic development in Nigeria, effective fire safety training program which would assist the fire safety manager, building manager and fire safety practitioners. Adequate fire safety training of the building occupants should be prioritized by the stakeholders in the field of fire safety, especially in the area of fire safety measure installed in building.

\section{Acknowledgment}

The researchers would like to appreciate the support of the TRG Campus from UTM through cost center No R.J 130000.7751.4J343

\section{References}

Agyekum, K., Ayarkwu, J., \& Ayarkwa, D.-G. (2016). Fire Safety Awareness and Management in MultiStorey Students Hotel. ASIAN Journal of Applied Science, 329-338.

Ali, A. (2006). Conducting Research in Education ansd Social Sciences. Tashiwa Net Woness. 
Campbell, R. (2020). Using OSHA Investigation Summaries to Profile Fatal Work Injuries Involving Fire. Fire Technology.

Chandrashekara, K. S. (2012). Sample Size Estimation and Power Analysis Studie. Journal of Human Reproductive Science.

Chow, W. (2001). Review on Fire Safety Management and Application to Hong Kong. International Journal on Engineering Performance-based Fire Code.

Debora, K. (2019). An emperical Evaluation of Fire outbreak Management in Ghana. AshEse Journal of Business Management, 154-183.

Ferrontato, N., \& Torretta, V. (2019). Waste Management in Developing Countries; A review of Global issues. International Journal of Environmental Research Public Health.

FPA. (2009). Fire Prevention' Fire Engineer Journal. International Journal for fire Proffessional. Georgia. (2018). Road Safety Performance Review. United Nation New York and Geneva.

Groner, N. E. (2016). A decision model for recommending which building occupants should move where during fire. Fire Safety Journal, 20-29.

Ho, Y. Y. (2009). The Effects of Building Management Practice on Residential Price in Hong Kong. Journal of Building Appraisal.

Howarth, D. A.-Z. (1999). Fire Safety Management at Passenger Terminals. Disaster Prevention Management, An international Journal, 362-369.

Kodure, P. K. (2019). Fire Hazard in Buildings; review assesment and Strategies for Improving Fire Safety. Emralt Insight Journal.

Kuru, O. N., Omuteremu, S., \& Nyandiko, N. (2017). Evaluating The Effectiveness of Fire Safety Training on Occupants Response in Selective Public Building. International Journal of Science: Basic and Applied Research, 166-173.

Martin, N. (2013). Fire Safety Evaluation of Multifunctional Buildings. Thesis of Lund University.

Nimlyat, P. S., Audu, A. U., \& Gwatau, E. O.-A. (2017). An evaluation of Fire Safety Measure in High-rise Buildings in Nigeria. Sustainable Cities and Society, 774-785.

Qureshi, G. G. (2018). Exploratory Qualitative Study of Fire Preparedness Among High-rise building. Current Disaster PLO.

Ronchi, E. (2013). Fire Evacuation in High-rise building: a review of human behavous and modelling research. Fire Science Review.

Santin, S. H. (2016). Global trends in Wildlife and its Impcts Perception Versus realities in changing work. Philosophical Transaction.

Santos, J. R. (1999). Cronbach Alpha: A tool for Assessing the reliability of Scale. Journal Extension.

Shokouhi, M., Nasiriani, K., Khankeh, H., Fallahzadeh, H., \& Zavareh, D. K. (2019). Exploring Barriers and Challenges in Protecting Residential Fire-Related Injuries: a qualitatative Study. Journal of Injury and Violence, 81-92.

Todaro, B., \& Fideli, L. \&. (2007). Using multivariate statistic. Pearson Boston, M.A.

Wheaton, B., Muthen, B., \& Alwin, D. \&. (1977). Assessing reliability and stability in panel models. Sociological methodology, (pp. 84-136).

YAYUN, W. (2016). Reseaerch on Public Building Fire Risk Assesment Control Model. Chines Control and Decision Conference, 23-30. 